\title{
Isolation and Screening of Lignin Degrading Bacteria from Different Natural and Organic Sources
}

\author{
N. Umashankar ${ }^{1 *}$, H.M. Meghashree ${ }^{2}$, P.S. Benherlal ${ }^{3}$ and Mohan Chavan $^{3}$ \\ ${ }^{1}$ Department of Agricultural Microbiology, University of Agricultural Sciences, \\ GKVK, Bangalore, Karnataka State, India \\ ${ }^{2}$ Centre for Incubation, Innovation, Research and Consultancy (CIIRC), Jyothy \\ Institute of Technology, Tataguni, Kanakapura Road, \\ Bangalore - 560082, Karnataka, India \\ ${ }^{3}$ Department of Plant Biotechnology, University of Agricultural Sciences, \\ GKVK, Bangalore, India \\ *Corresponding author
}

\section{Keywords}

Maizecob, degradation, Lignin degrading bacteria, SDS - PAGE, Laccase

\section{Article Info}

Accepted: 07 November 2018 Available Online: 10 December 2018

\section{A B S T R A C T}

Increased consumption and high dependence on non - renewable sources has substantially contributed to global warming and environmental pollution. Hence, alternative strategies for energy production have to be looked and one of the alternative is producing $2^{\text {nd }}$ generation Bio-ethanol from lingo-cellulosic material. Maize cob is one of the Lignocellulosic material is one the substrate, which can be used for Bio-ethanol production (It is rind after removing the seeds). The present study is focused on to look for novel strains of lignin degrading bacteria from various organic sources. The different sample sources used for the isolation of lignin degrading bacteria were from cow dung, compost, forest soil, garden soil in agriculture college, Hassan. Enrichment of sample source was also done by mixing the paper, corncob, compost, cowdung and soil in different proportions and kept for 15 days at room temperature. Enriched samples were also used as a source for isolation of lignin degraders. Totally 64 colonies were isolated by screening in 7 different sample sources, from those 64 isolates, only 25 isolates confirmed as lignin degraders through conformational test. Decolourization zone produced by 25 isolates was measured. Eight isolates that produced large decolurization zone $(0.5$ to $1 \mathrm{~cm})$ were selected and further screened for their tolerance to lignin by culturing them on $2 \%$ lignin. The results pertaining to growth on $2 \%$ Alkaline lignin is, isolate $\mathrm{CC}-10$ was grown within $24 \mathrm{hr}$ followed by CM-3, PC- 2,PC- 3 , PC-5 and CC- 8 they were grown within $48 \mathrm{hr}$. The growth of FS- 3 and CC-10 were seen within $72 \mathrm{hr}$. Based on the results obtained the slow grower FS-3 and CC-10 was discarded. Six potential isolates which are showing large clear zone (decolourized) of methylene blue dye and also rapid growth on MSM with $2 \%$ alkaline lignin were selected. Based on this to reconfirm the isolates as a lignin degrading bacteria Protein profiling of the six isolates has been done by using SDS PAGE technique. 


\section{Introduction}

India is sixth in the world energy need and overall demand of crude oil is raised by $5.6 \%$ until 2011. The scenario of rising and volatile prices in world oil market and respective foreign exchange cost are the main risk factors for Indian economy and social development prospects. Further, increased consumption and high dependence on non - renewable sources has substantially contributed to global warming and environmental pollution. Hence, an alternative strategy for energy production has to be looked and one of the alternative is producing $2^{\text {nd }}$ generation Bio-ethanol from lignocellulosic material. In Karnataka State, maize is grown in an area of 12.43 lakh hectares with an annual production of 30.15 lakh tonnes, out of this around 20 lakh tonnes of maize cobs is produced after the processing (Project director review, 2013, AICRP on Maize). The residue left over after harvesting of maize is the thrash and the cobs (It is rind after removing the seeds). The thrash is directly used as feed to the farm animals and cobs are very rigid in nature because of high lignocelluloses and presently the farmers are mainly using maize cobs as a fuel purpose (Direct burning for cooking purpose) which releases lot of Carbon materials to the environment and create environmental pollution. Lignin is the most structurally complex, possessing a high molecular weight and the most recalcitrant, consisting of various biologically stable linkages (Perez et al., 2001). The plant cell wall consists of. cellulose, hemicelluloses, pectic substances and lignin. After cellulose, lignin is the second most abundant renewable biopolymer in the biosphere (Rahman et al., 2013). The breaking of lignocellulosic material is very difficult due to its complex structure (Himmel et al., 2007), it has to be broken down to release fermentable sugars which can be utilized further for Bio ethanol production. There are various physical, chemical and biological methods have been developed to degrade lignocellulosic material, which are expensive and energy consuming. The present study is focused on to look for novel strains of lignin degrading bacteria from various organic sources, which can be a cost effective method to degrade maize cob and further used for the production of bio-ethanol production.

\section{Materials and Methods}

The study was executed at the College of agriculture, Hassan (University of Agricultural Sciences, Bangalore), Karnataka.

\section{Isolation of bacteria from different organic sources}

The different sample sources used for the isolation of lignin degrading bacteria were from cow dung, compost, forest soil, garden soil in college of agriculture, Hassan. Enrichment of sample source was done by mixing the paper, corncob, compost, cowdung and soil in a different ratios and kept for 15 days at room temperature [Compost+ Soil+ Paper (4:2:1), Compost+Soil+Maize cob (4:2:1), Compost+Soil+Cowdung (2:2:1)]. Enriched samples were also used as a source for isolation of lignin degraders (Table 1).

The specific media used for isolation is minimum salt medium agar containing alkaline lignin (MSML-agar). Media Composition is $\mathrm{K}_{2} \mathrm{HPO}_{4}, 4.55 \mathrm{~g}$; $\mathrm{NH}_{4} \mathrm{NO}_{3}, 5 \mathrm{~g}$; $\mathrm{H}_{3} \mathrm{BO}_{3}, 0.5 \mathrm{~g} ; \mathrm{CaCl}_{2}, 0.01 \mathrm{~g} ; \mathrm{KH}_{2} \mathrm{PO}_{4}, 0.53 \mathrm{~g}$; Trace element solution $1 \mathrm{ml}\left(\mathrm{ZnSO}_{4} \cdot 7 \mathrm{H}_{2} \mathrm{O}\right.$, $2.2 \mathrm{~g} ; \mathrm{Mn}$ acetate, $0.5 \mathrm{~g} ; \quad \mathrm{FeCl}_{3}, 0.5 \mathrm{~g}$; $\mathrm{CuSO}_{4} .6 \mathrm{H}_{2} \mathrm{O}, 0.16 \mathrm{~g}$; Molybdic acid, 0.11g; $\mathrm{Na}_{2}$ EDTA, 5g; and distilled water, $1000 \mathrm{ml}$ ) and distilled water $1000 \mathrm{ml}$. Isolation was done using the procedure followed by Sasikumar et al., (2014).

MSML media consisted of $1 \%$ alkaline lignin is used for isolation of bacteria. Alkaline 
lignin was prepared by using maize cob substrate. With $6 \mathrm{~g}$ maize cob powder, $40 \mathrm{ml}$ of $1 \% \mathrm{H}_{2} \mathrm{SO}_{4}$ was added and heated in hot air oven at $80^{\circ} \mathrm{c}$ for $20 \mathrm{~min}$. Allowed to cool, followed by $150 \mathrm{ml}$ of $4 \% \mathrm{NaOH}$ was added and boiled for $30 \mathrm{~min}$. The dark brown coloured alkali lignin was filtered and autoclaved at $15 \mathrm{lbs}$ for $15 \mathrm{~min}$. Inoculation was done by placing $5 \mathrm{~g}$ sample in $100 \mathrm{ml}$ broth and incubated at $120 \mathrm{rpm}$ for 7 days at $38.5^{\circ} \mathrm{c}$ temperature. Enriched sample of $1 \mathrm{ml}$ were transferred to $99 \mathrm{ml}$ of sterile $\mathrm{NaCl}$, this solution was stirred vigorously and allowed to settle down. Using $1 \mathrm{ml}$ of the liquid mixture, serial dilution was performed up-to $10^{-7}$. From each dilution about $100 \mu$ l of sample was spread on plate containing MSML agar. Plates were incubated at $30^{\circ} \mathrm{c}$ for 7 days until colonies were developed. Isolated colonies were streaked onto fresh MSML agar plates repeatedly to obtain pure culture.

\section{Confirmation test for screening lignolytic activity}

According to Sasikumar et al., (2014), isolated colonies were screened by using methylene blue dye as an indicator. Pure cultures were streaked on methylene blue containing ( 0.25 $\mathrm{g} / \mathrm{L})$ containing LB agar plate. Plates were incubated at $30^{\circ} \mathrm{c}$ for $72 \mathrm{hr}$. The microbes posses' lignolytic enzymes undergoes oxidation of indicator dye resulting in decolourisation of methylene blue. The decolourised colonies were selected as lignin degraders. The selected isolates were maintained through sub-culturing and also maintained at $4^{\circ} \mathrm{c}$ temperature.

\section{Screening of the microbial isolates on $2 \%$ alkaline lignin}

The eight isolates further screened to know the potentiality of utilizing 2\% Alkaline lignin as a sole carbon source and grow. The Microbial isolates were plated on Minimal media containing 2\% Alkaline lignin and observed the growth over a period of 72 hours (Chandra et.al., 2010).

Eight isolates showing large decolourization zone $(0.5$ to $1 \mathrm{~cm})$, were inoculated in MSM agar plate amended with $2 \%$ alkaline lignin. Growth was observed daily. On the basis of growth rate, isolates were distinguished as, very fast grown isolates which were grown within 24 hours, fast grown isolates grown within 48 hours and slow grown isolate grown after 48 hours. Among eight isolates, one isolate (CC-10) was grown within 24 hours, five isolates (CM-3, PC-2, PC-3, PC-5 and $\mathrm{CC}-8)$ were grown within 48 hours and two isolates (FS-3, CC-9) were grown after 48 hours. Six isolates showing rapid growth $(\mathrm{CC}-$ 10, CM-3, PC-2, PC-3, PC-5 and CC-8) on MSM agar with 2\% alkaline lignin was selected (Table 2) as potential isolates to degrade lignocellulosic biomass.

\section{Protein profiling of the screened microbial isolates}

SDS PAGE was done to check whether selected isolates are producing laccase enzyme. Bands were compared with three standard protein bands BSA (Bovine sereum albumin), Amylase and Protinase of band size of 66,54 and $28 \mathrm{kDa}$ respectively. Molecular size of sample proteins was determined using Image J software. Protein bands produced by isolates from both minimal media without cob and minimal media with cob were compared and it was observed that some isolates showed large size of protein bands isolated from media with cob compared to media without cob. So the isolates which were producing extra proteins in media with cob may considered as lignocellulose degrading enzymes and that isolates were further checked for their capacity to produce reducing sugars and phenolics by degrading maize cob. By analysing all the three parameters (protein, 
reducing sugars and phenolics), finally three efficient isolates (PC-5, CM-3, PC-2) were selected for maize cob hydrolysis.

Protein profiling is done by using SDS PAGE to check whether selected isolates are producing laccase enzyme. Bands were calibrated with three standard protein viz. bovine serum albumin $64 \mathrm{KDa}$ ), amylase (54 $\mathrm{KDa})$ and Protease (24 KDa). Molecular size of sample proteins were calculated using Image $\mathbf{J}$ software developed at the National Institutes of Health and the Laboratory for Optical and Computational Instrumentation (LOCI, University of Wisconsin). Further the microbial isolates were grown in two conditions; one with Nutrient Media (where all the nutrients are available for the growth) and another minimal media with maize cob as sole carbon source.

Protein extraction (Bhaduri and Demchick, 1983)

Isolates were inoculated into both LB broth and minimal media containing $1 \mathrm{~g}$ maize cob powder, allowed to growth for 24 hour and stored in a refrigerator. $2 \mathrm{ml}$ of broth culture was taken in microfuge tube and then centrifuged at $7000 \mathrm{~g}$ for 15 minutes. The supernatant was discarded, pellet was washed with $0.9 \%$ saline twice. The cells were then suspended in $2 \mathrm{ml}$ of acetone (Ice cold) and allowed to stand on ice for $5 \mathrm{~min}$ and collected by centrifugation. Then cells were suspended in $1.5 \mathrm{ml}$ of $1 \% \mathrm{SDS}$ and disrupted using sonicator. This whole total cell protein extract was used for protein estimation and profiling by Sodium Dodecyl Sulphate-Poly Acrylamide Gel Electrophoresis (SDS PAGE)

\section{SDS-Poly Acrylamide Gel Electrophoresis (SDS PAGE)}

Vertical slab gel electrophoresis unit was set to run SDS PAGE. $10 \%$ Resolving gel (water, 19.8ml; 30\% Acrylamide:Bisacrylamide, 16.7 $\mathrm{ml} ; 1.5 \mathrm{M}$ Tris (pH 8.8), $12.5 \mathrm{ml} ; 10 \%$ SDS, $0.5 \mathrm{ml} ; 10 \%$ APS, $0.5 \mathrm{ml}$; TEMED, $20 \mu \mathrm{l}$ ) was poured up-to $3 / 4$ level between the glass plates and overlay with isopropanol for normalization of the gel edges. After polymerization isopropanol was removed and washed with double distilled water. Comb was placed and 5\% stacking gel (water, 6.8ml; $30 \%$ Acrylamide:Bisacrylamide, $1.7 \mathrm{ml} ; 1 \mathrm{M}$ Tris (pH 6.8), $1.25 \mathrm{ml} ; 10 \%$ SDS, $0.1 \mathrm{ml}$; $10 \%$ APS, $0.1 \mathrm{ml}$; TEMED, $10 \mu \mathrm{l}$ ) was poured and allowed to polymerize, then comb was removed without distorting the shapes of the well. Carefully gel was installed into the electrophoresis unit with the reservoir buffer (1M, Tris glycine buffer, $\mathrm{pH}$ 8.5). Samples were prepared by mixing it with loading dye in the proportion of $45 \mu \mathrm{l}$ sample and $15 \mu \mathrm{l}$ loading dye (60mM Tris HCL (pH 6.8), 0.6ml, $2.5 \%$ SDS, 2.5ml; glycerol, $1 \mathrm{ml} ; \quad \beta$ Mercaptoethanol, $250 \mu \mathrm{l} ; 0.002 \%$ Bromo phenol blue, $20 \mu \mathrm{l}$ ) and then placed it in a boiling water bath for 5-10 minutes for destabilization and incorporating the uniform charges to the protein for electrophoresis. Samples and standard proteins were loaded into well and connected the unit to electrical power pack and run at $120 \mathrm{~V}$ for 6 hours (Kurien and Scofield, 2012).

\section{Staining and Destaining (Kurien and Scofield, 2012)}

After electrophoresis, gel was removed from glass plates and transferred to staining tray and rinse in a fixing solution (Fixing solution $(100 \mathrm{ml})$ : Glacial Acetic Acid, $10 \mathrm{ml}$; Methanol, $50 \mathrm{ml}$;Water: $40 \mathrm{ml}$ ) for about 10 minutes. Then poured off the fixing solution. Rinsed with water for 30 seconds. Then added $150 \mathrm{ml}$ of staining solution (Staining solution $(100 \mathrm{ml})$ : Coomassie brilliant blue R250, $0.25 \mathrm{~g}$; Glacial Acetic Acid, $10 \mathrm{ml}$; Methanol, $50 \mathrm{ml}$; Water: $40 \mathrm{ml}$ ), kept in microwave for 50 to 60 seconds until the 
solution just starts to boil. Incubate at room temp with gentle shaking for 2-5 min. Heating allows the gel to stain faster. Poured off the staining solution and then repeated the process with another fresh $150 \mathrm{ml}$ of staining solution. Poured off the staining solution and then rinsed the gel with water for 15 seconds. Then added $150 \mathrm{ml}$ of distaining solution (Destaining solution (200 ml): Glacial Acetic Acid, $20 \mathrm{ml}$; Methanol, $100 \mathrm{ml}$; Water, $80 \mathrm{ml}$ ), kept in microwave for 40 to 50 seconds, kept in gentle shaker for 10 minutes at room temperature. Poured off the destaining solution and repeated the cycle with fresh destaining solution for 3 to 4 times. Blue stained bands on the gel were observed and image was captured under gel documentation unit.

\section{Results and Discussion}

The different sample sources used for the isolation of lignin degrading bacteria and total number of colonies screened and confirmed isolates from each source are tabulated in table 1. Totally 64 colonies were isolated by screening in 7 different sample sources, from those 64 isolates, only 25 isolates confirmed as lignin degraders through conformational test (Table 2 and Figure 1). The decolourization of methylene blue has been used previously as an indicator of lignin peroxidise enzyme activity (Ferrer'ra - leitao et al., 2007), which is one of the enzyme responsible for lignin degradation. Maximum of 11 isolates were isolated from maize cob enriched sample only, 5 isolates from paper enriched sample, 4 from compost and cowdung enriched sample. From forest soil, 3 isolates were showed positive, while from garden soil and cowdung, one isolate each showed positive in conformational test. Decolourization zone produced by 25 isolates was measured and presented in Table 2.

Eight isolates that produced large decolurization zone $(0.5$ to $1 \mathrm{~cm})$ were selected and further screened for their tolerance to lignin by culturing them on $2 \%$ lignin.

The results pertaining to growth on $2 \%$ Alkaline lignin is presented here CC- 10 was grown within $24 \mathrm{hr}$ followed by CM-3, PC2,PC- 3, PC-5 and CC- 8 they were grown within $48 \mathrm{hr}$. The growth of FS- 3 and CC-10 were seen within $72 \mathrm{hr}$. Based on the results obtained the slow grower FS-3 and CC-10 were discarded (Table 3). The capability of soil isolated bacteria to degrade efficiently and assimilated lignin as a sole carbon sources agreed with findings of Morrii et., al., (1995) and Hassan and Hanafy, (2009) (Fig. 2 and 3).

Table.1 Total number of colonies screened and confirmed isolate

\begin{tabular}{|l|l|c|c|}
\hline SI.No. & Sample source & $\begin{array}{c}\text { Number of colonies } \\
\text { screened }\end{array}$ & $\begin{array}{c}\text { Number of } \\
\text { Confirmed isolates }\end{array}$ \\
\hline $\mathbf{1}$ & Cowdung & 7 & 1 \\
\hline $\mathbf{2}$ & Compost & 7 & 0 \\
\hline $\mathbf{3}$ & Compost+Soil+Paper $(4: 2: 1)$ & 8 & 5 \\
\hline 4 & Compost+Soil+Maize cob $(4: 2: 1)$ & 13 & 11 \\
\hline $\mathbf{5}$ & Compost+Soil+Cowdung $(2: 2: 1)$ & 9 & 4 \\
\hline 6 & Forest Soil & 9 & 3 \\
\hline 7 & Garden Soil & 11 & 1 \\
\hline Total & & 64 & 25 \\
\hline
\end{tabular}


Table.2 Screening of confirmed colonies using decolourization of methylene blue in LB media

\begin{tabular}{|c|c|c|}
\hline Sl.No & Isolate No. & $\begin{array}{c}\text { Zone of } \\
\text { decolourization }(\mathrm{cm})\end{array}$ \\
\hline 1 & CM-3 & 1 \\
\hline 2 & $\mathrm{CC}-8$ & 1 \\
\hline 3 & PC-5 & 0.8 \\
\hline 4 & FS-3 & 0.6 \\
\hline 5 & PC-2 & 0.6 \\
\hline 6 & PC-3 & 0.5 \\
\hline 7 & CC-9 & 0.5 \\
\hline 8 & CC-10 & 0.5 \\
\hline 9 & $\mathrm{CC}-4$ & 0.4 \\
\hline 10 & CM-2 & 0.3 \\
\hline 11 & CM-4 & 0.3 \\
\hline 12 & PC-1 & 0.3 \\
\hline 13 & CC-5 & 0.2 \\
\hline 14 & GS-1 & 0.1 \\
\hline 15 & CC-1 & 0.1 \\
\hline 16 & CC-3 & 0.1 \\
\hline 17 & C-11 & 0.1 \\
\hline 18 & CC-7 & 0.08 \\
\hline 19 & CW-1 & 0.05 \\
\hline 20 & FS-2 & 0.05 \\
\hline 21 & PC-4 & 0.05 \\
\hline 22 & $\mathrm{CC}-2$ & 0.05 \\
\hline 23 & CC-6 & 0.04 \\
\hline 24 & FS-1 & 0.03 \\
\hline
\end{tabular}

Table.3 Isolates grown on 2\% Alkaline lignin for measurement of their tolerance

\begin{tabular}{|l|c|c|}
\hline SI.No & Isolate no. & Growth rate \\
\hline 1 & FS-3 & + \\
\hline 2 & CM-3 & ++ \\
\hline 3 & PC-2 & ++ \\
\hline 4 & PC-3 & ++ \\
\hline 5 & PC-5 & ++ \\
\hline 6 & CC-8 & ++ \\
\hline 7 & CC-9 & + \\
\hline 8 & CC-10 & +++ \\
\hline
\end{tabular}

+++ ; very fast growth(within $24 \mathrm{hr}$ )

++ ; fast growth(within $48 \mathrm{hr}$ ), +; slow growth(within $72 \mathrm{hr}$ ) 
Table.4 Molecular weight of proteins produced by isolates grown both in Nutrient broth without cob and Minimal media containing cob

\begin{tabular}{|l|l|l|}
\hline $\begin{array}{l}\text { Sl. } \\
\text { No }\end{array}$ & Isolate No & Minimal media with cob (kDa) \\
\hline $\mathbf{1}$ & PC-5 & $\mathbf{9 6 , 9 2 , 8 7 , 7 8 , 6 7 , 6 2 , 5 3 , 5 0 , 3 8 , 2 6 , 1 7}$ \\
\hline $\mathbf{2}$ & CC-8 & $84,82,79,74,66,63,58,51,43,36,20$ \\
\hline 3 & CM-3 & $\mathbf{9 7 , 9 1 , 8 6 , 7 9 , 6 8 , 6 2 , 5 4 , 5 0 , 4 1 , 3 6 , 3}$ \\
\hline $\mathbf{4}$ & PC-2 & $\mathbf{9 7 , 9 3 , 8 5 , 7 6 , 6 9 , 6 6 , 6 4 , 6 0 , 5 7 , 4 8 , 4 5 , 4 2 , 3 0 , 2 7}$ \\
\hline 5 & PC-3 & $\mathbf{7 8 , 7 0 , 6 7 , 6 5 , 6 2 , 5 7 , 4 5 , 3 5 , 2 9}$ \\
\hline $\mathbf{6}$ & CC-10 & $\mathbf{9 7 , 9 3 , 6 3 , 5 0 , 4 0}$ \\
\hline
\end{tabular}

Figure.1 Decolourization of methylene blue in LB media by isolates

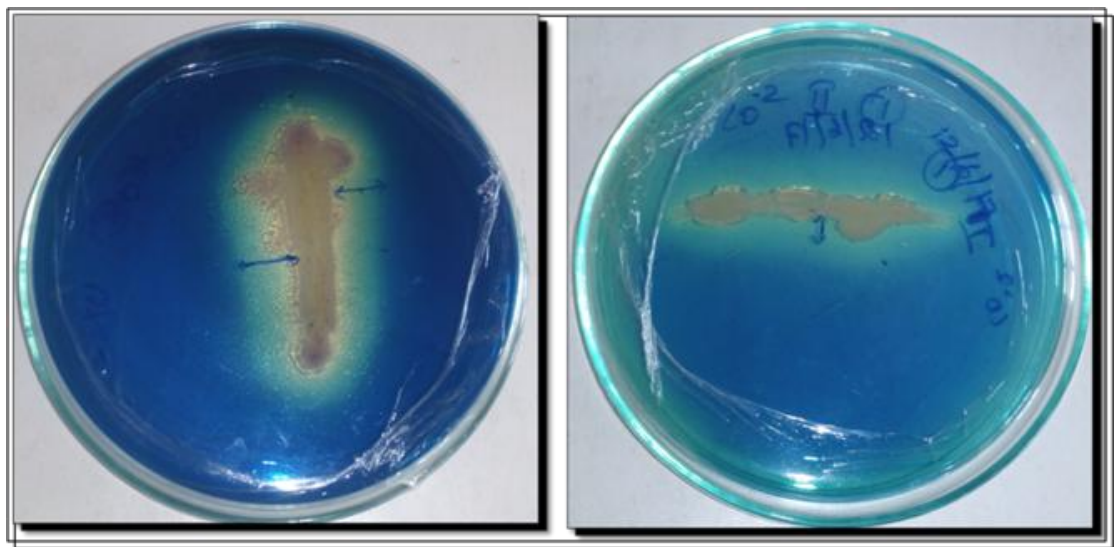

Figure.2 Protein profile of the six isolates grown in minimal media with cob

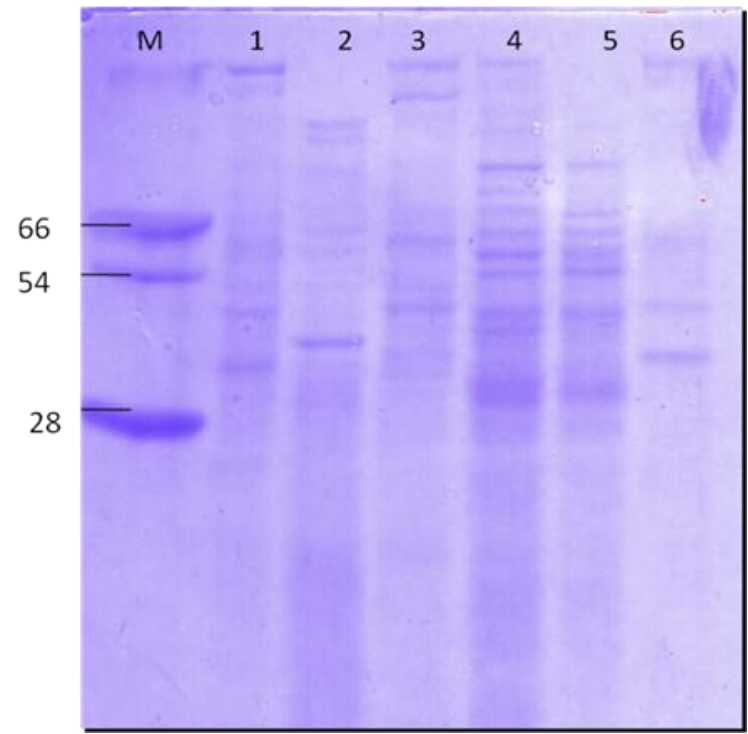

(M: Molecular weight standard 66, 54 and 28 kDa; 1: PC-5; 2: CC-8; 3: CM-3; 4: PC-2; 5: PC-3; 6: CC-10.) 
Figure.3 Protein profile of the six isolates grown in nutrient broth without cob

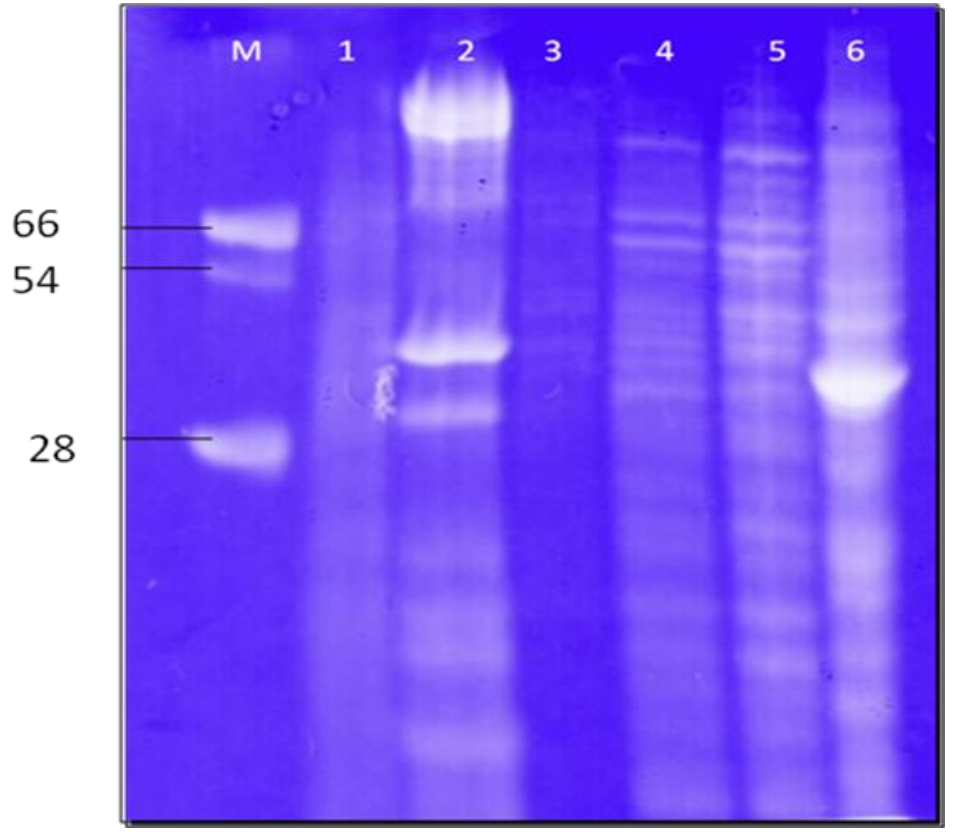

(M: Molecular weight standard 66, 54 and 28 kDa; 1: PC-5; 2: CC-8; 3: CM-3; 4: PC-2; 5: PC-3; 6: CC-10.)

Six potential isolates which are showing large clear zone (decolourized) of methylene blue dye and also rapid growth on MSM with $2 \%$ alkaline lignin were selected. Further these 6 isolates can be used in studies related to biodegradation of maize cob (Table 4).

To degrade the lignin, organisms has to produce extracellular enzymes, namely Laccases, Lignin peroxidises (LiPs), Manganese peroxidises (MnPs) and Versalite peroxidises (Buggy et al., 2011; Hatakka, 1994). Based on this to reconfirm the isolates as a ligning degrading bacteria Protein profiling of the six isolates has been done by using SDS - PAGE technique to check the organisms is producing Laccases enzyme as an indicator. Protein bands produced by isolates grown in both minimal media without cob and minimal media with cob were compared and it was observed that some isolates showed expression of a certain prominent bands as an indication of differential gene expression. Therefore, the isolates grown in minimal media with maize cob and producing extra proteins may be considered as lignocellulose degrading enzymes (Ahmad et al., 2011), finally three efficient isolates (PC-5, CM-3, PC-2) were selected for maize cob hydrolysis.

\section{Acknowledgement}

The authors Acknowledge Science and Engineering Research Board, Department of Science and Technology, Government of India under Empowerment and Equity opportunities for excellence in Science Programme EMEQ for the financial support to conduct this research work.

\section{References}

Ahmad, M., Roberts, J.N., Hardiman, E.M., Singh, R., Eltis, L.D., Bugg, T.D.H. 2011., Identification of DypB from Rhodococcus jostii RHA1 as a lignin peroxidise. Biochemistry. 50 (23):5096 $-5107$.

Annual Report, 2013. Project director review, AICRP on Maize, Zonal Agricultural Research Station, V. C. Farm, Mandya. 
Bhaduri, S. and Demchick, P. H., 1983, Simple and rapid method for disruption of bacteria for protein studies, Appl. Environ. Microbiol, 46(4):941-943.

Bugg, T.D.H., Ahmad, M., Hardiman, E.M. and Sigh, R., 2011. The emerging role for bacteria in lignin degradation and bio - product formation. Curr Opin Biotechnol. 22(3):394-400.

Chandra, R., Raj, A., Purohit, H. J. and Kapley, A., 2007. Characterization and optimization of three potential aerobic bacterial strains for kraft lignin degradation from pulp paper waste, Chemosphere. (67): 839-846.

Ferreir - leitao, V.S., Andrade de Carvalho, M.E. and Bon, E.P.S., 2006. Lignin peroxidise efficiency for methylene blue decolouration: comparison to reported methods. Dye. Pigment. 4:230 - 236.

Hassan, E.A.. and Hanafy, A.A.E., 2009. Lignin biodegradation with lignolytic bacterial strain and comparison Bacillus subtillis and Bacillus sp. Isolated from Egyptian soil. Am - Euros. J. Agric \& Environ. Sci. 5(1): 39- 49.

Hatakka, A., 1994. Lignin - modifying enzyme from selected white - rot fungi: Production and role in lignin degradation. FEM Microbol. Rev., 13:125-135.

Himmael, M.E., Ding, S.Y., Johnson, D.K.,
Adney. W.S., Nimlos, M.R., Brady, J.W., Foust, T.D., 2007. Biomass recalcitrance: Engineering plants and enzymes for biofuels production. Science. 315(5813):804-807.

Kurien, B. T and Scofield, R. H., 2012, Accelerated Coomassie blue staining and destaining of SDS-PAGE gels with application of heat, Methods in Molecular Biology, Protein Electrophoresis, volume 869, Springer, DOI 10.1007/978-1-61779-821-4-41.

Morrii, H.K., Nakamiya and Kinoshita, S., 1995. Isolation of lignin decolourising bacterium. J. Ferment. Bioeng., 80:296299.

Perez, J., Rubia, T.D.L., Marbinez, J. And Kapley, A., 2001. Biodegradation and biological treatment of cellulose, hemicelluloses and lignin: An overview. Int. Microbiol. 5:53-63.

Rahman, N.H.A., Rahman, N.A.A., Surainiabdaziz, M. And Hassan, M., 2013. Production of lignolytic enzymes by newly isolated bacteria from palm oil plantation soils. Bioresour. 8(4): 61366150.

Sasikumar, V., Priya, Shankar, C. S., Sekar, D. S., 2014, Isolation and preliminary screening of lignin degrading microbes, J. Acad. Indus. Res, 3(6): 291-294.

\section{How to cite this article:}

Umashankar, N., H.M. Meghashree, P.S. Benherlal and Mohan Chavan. 2018. Isolation and Screening of Lignin Degrading Bacteria from Different Natural and Organic Sources. Int.J.Curr.Microbiol.App.Sci. 7(12): 609-617. doi: https://doi.org/10.20546/ijcmas.2018.712.075 